\title{
Bruna Donatelli, Paradigmi della modernità, Letteratura, arte e scienza nella Francia del XIX secolo
}

\author{
Ida Merello
}

\section{(2) OpenEdition}

\section{Journals}

\section{Edizione digitale}

URL: http://journals.openedition.org/studifrancesi/2252

DOI: 10.4000/studifrancesi.2252

ISSN: 2421-5856

\section{Editore}

Rosenberg \& Sellier

\section{Edizione cartacea}

Data di pubblicazione: 1 aprile 2014

Paginazione: 178

ISSN: 0039-2944

\section{Notizia bibliografica digitale}

Ida Merello, «Bruna Donatelli, Paradigmi della modernità, Letteratura, arte e scienza nella Francia del xIx secolo », Studi Francesi [Online], 172 (LVIII | I) | 2014, online dal 01 avril 2014, consultato il 18 septembre 2020. URL : http://journals.openedition.org/studifrancesi/2252 ; DOI : https://doi.org/ 10.4000/studifrancesi.2252

Questo documento è stato generato automaticamente il 18 settembre 2020.

\section{(c) (i) (9)}

Studi Francesi è distribuita con Licenza Creative Commons Attribuzione - Non commerciale - Non opere derivate 4.0 Internazionale. 


\title{
Bruna Donatelli, Paradigmi della modernità, Letteratura, arte e scienza nella Francia del XIX secolo
}

\author{
Ida Merello
}

\section{NOTIZIA}

BRUNA DONATELLI, Paradigmi della modernità, Letteratura, arte e scienza nella Francia del XIX secolo, Roma, Artemide, 2012, pp. 171.

1 Il volume, a carattere essenzialmente divulgativo, riunisce sotto il titolo ad ampio spettro una serie di capitoli che non mostrano alcun carattere unitario. L'A. presenta aspetti dell'opera, o l'opera in generale, di autori che sono stati rappresentativi della modernità nel XIX secolo. Ripropone così il confronto tra Barbey D'Aurevilly e Baudelaire, ricordando la reciproca stima e l'analoga declinazione della figura del dandy come immagine del disprezzo; traccia quindi un percorso attraverso l'opera di Flaubert, a partire dallo snodo tra la Tentation e Mme Bovary fino alle ultime opere, ricordando l'importanza del concetto di una scrittura «sul nulla» nell'evoluzione della storia del romanzo. Un altro capitolo è dedicato ad Avatar, e al suo tipo di fantastico «en habit noir» (che, insieme a Jettatura, sarebbe dovuto rientrare in un trittico), con riflessioni sui diversi personaggi. Segue infine un capitolo sulla fotografia, dove l'A. prende in considerazione i giudizi nei suoi confronti via via di Baudelaire, Flaubert, Lamartine, per arrivare al dibattito sullo statuto artistico della fotografia degli anni Settanta e all'allusione alla fotografia nel romanzo e racconto fin de siècle. Il volume si conclude con un capitolo sui rapporti tra Félicien Rops e Baudelaire, e uno sui viaggi di Hyppolite Taine. 